DOI: 10.20472/IAC.2017.33.031

\title{
GINDRUTE KASNAUSKIENE
}

Vilnius university, Lithuania

\section{KAROL MICHNEVICH}

Vilnius university, Lithuania

\section{CONTRIBUTION OF INCREASED LIFE EXPECTANCY TO ECONOMIC GROWTH: EVIDENCE FROM CEE COUNTRIES}

\begin{abstract}
:
Population ageing in a backdrop of growing average life expectancy can be seen in many advanced economies, but the rapid pace of these demographic changes in Central and Eastern Europe (CEE) makes it a pressing matter for the region. We investigate these two phenomenon and compare results with prior research to determine their separate and combined effect on output growth in a panel regression model using Eurostat data for the period 1996 to 2013. Our findings point to both life expectancy and population ageing exerting a statistically significant, overlapping effect on real output. The conclusions of our research demonstrate the utility of augmenting macroeconomic models with a demographics-sensitive component.
\end{abstract}

\section{Keywords:}

demographics, life expectancy, population ageing, economic growth, CEE countries

JEL Classification: E10, J10, J11 